\title{
Control of the Root-Knot Nematode Meloidogyne incognita and Weeds in Protected Cucumber with Dimethyl Disulfide (DMDS) over Two Crop Cycles: The First Results in Hungary
}

\author{
F. TÓTH ${ }^{1 *}$, FRANCISKA TÓTHNÉ BOGDÁNYI ${ }^{2}$, RENÁTA PETRIKOVSZKI ${ }^{1}$, \\ ANITA GÓDOR ${ }^{1}$, M. ZALAI ${ }^{1}$, B. BÁLINT ${ }^{3}$, P. SUNDER $^{4}$ and A. MYRTA ${ }^{5}$ \\ 'Plant Protection Institute, SZIE MKK, H-2100 Gödöllő, Páter Károly u. 1., Hungary \\ ${ }^{2}$ FKF Nonprofit Zrt., H-1081 Budapest, Alföldi u. 7., Hungary \\ ${ }^{3}$ Certis Europe, Budapest \\ ${ }^{4}$ Certis Europe Services, Marguerittes, France \\ ${ }^{5}$ Certis Europe B.V., Maarssen, The Netherlands
}

(Received: 2 September 2019; accepted: 6 November 2019)

\begin{abstract}
The effectiveness of dimethyl disulfide (DMDS) to control root-knot nematodes (Meloidogyne spp.) and weeds was tested for the first time in Hungary in two consecutive protected cucumber crops with application made only before the first crop. The treatments were Accolade EC (DMDS 94.1\%) at 400 1/ha applied by driplines, Nemathorin $10 \mathrm{G}$ (fosthiazate) at $30 \mathrm{~kg} / \mathrm{ha}$, and an untreated control. During the first cucumber cycle vigour-index, yield, root-gall index, Meloidogyne juveniles in the soil and germination of weeds were evaluated. All considered parameters were significantly improved by using DMDS compared respectively to the chemical standard and untreated control: (i) vigour-index of 7.0, 4.3 and 3.6; (ii) cumulative yield/sample of $45.1 \mathrm{~kg}, 30.9 \mathrm{~kg}$, and $16.6 \mathrm{~kg}$; root-gall index (RGI) of 1.2, 4.9, and 5.9; (iii) M. incognita J2/25 g soil of $0.25,48.5$ and 78.0 , and (iv) number of weed seedlings/sample in the $20-30 \mathrm{~cm}$ soil profile of $1.1,2.6$, and 4.2. During the second cucumber crop, only root-gall index was evaluated. Results showed that a single DMDS treatment applied before the first crop had a prolonged beneficial effect on the following crop. In the second crop cycle, root gall indices were 5.58, 9.18, and 8.44 for DMDS treated plots, chemical control and untreated control, respectively.
\end{abstract}

Keywords: Soil fumigation, nematicide treatments, nematode and weed control, IPM.

Root-knot nematodes (Meloidogyne spp.) are polyphagous and wide-spread pests, causing significant yield losses in many vegetable crops. The most important symptoms include the yellowing of plants, stunted growth, and large and numerous galls on the roots, in which different developmental stages of nematodes (eggs, juveniles and mature females) can be found (Chitwood, 1949). The most widely distributed and abundant species of the genus are Meloidogyne incognita (Kofoid and White) Chitw., M. javanica (Treub) Chitw., M. hapla (Chitwood, 1949) and M. arenaria (Neal) Chitw. (Peacock, 1976; Fauna Europaea, 2019). 
Root-knot nematodes, when compared to other plant-parasitic nematodes, are the most damaging taxon and they have a large host range including staple crops (both annual and perennial) and weeds (Peacock, 1976; Sasser, 1977). The successful establishment and wide distribution of $M$. incognita is due to its adaptation to warm conditions and high reproductive potential, especially in sandy soils (Sasser, 1977). Since most of its host crop plants are of high economic importance, and because of the very low tolerance limit of host crops to Meloidogyne spp., usually less than one egg or second stage juveniles per $\mathrm{cm}^{3}$ of soil (Greco and Di Vito, 2009; Sasanelli et al., 2018), the species ranks high among pests affecting the economy of vegetable production. Root-knot nematodes reduce resistance against or increase the severity of infection of other soil-borne pathogens (Peacock, 1976; Sumner and Johnson, 1973; Marley and Hillocks, 1996; Chindo et al., 1991; Sasanelli et al., 2008, 2016; Gallo et al., 2011).

Meloidogyne incognita was first recorded in Hungary in 1958 (Andrássy, 1958), and it soon became the most common root-knot nematode species in protected crops (Dabaj et al., 1994; Mándoki and Pénzes, 2012).

Control of root-knot nematodes is generally based on chemical treatments: soil fumigations applied 3-4 weeks before planting and non-fumigant nematicides applied into the soil at sowing or transplanting (Basile et al., 2003; Wheeler et al., 2014). Following the phase-out of the biocide methyl-bromide, routinely used to control all kinds of biotic problems in protected vegetables, there is an increasing demand for more effective new compounds or eco-compatible control methods.

One of the most intriguing compounds developed for soil fumigation as alternative to methyl-bromide or other fumigants is dimethyl disulfide (DMDS), which occurs naturally in some plants especially in members of families Alliaceae and Brassicaceae (Gautier, 2007; Arnault et al., 2008; Charles and Heller, 2010). This active substance acts by disrupting the mitochondrial activity of neurons of the target organism (Gautier, 2007). DMDS, now being under registration process in EU by Arkema, but registered in many other countries, was found to be effective in the control of nematodes. Its use resulted in higher crop yield and improvement of crop quality, especially under protected conditions (Charles and Heller, 2010; Leocata et al., 2014; Myrta et al., 2018). Now, this product is under development by Certis Europe B.V., as part of the CleanStart ${ }^{\mathrm{TM}}$ program, a soil care strategy. DMDS was proven in European conditions to act as a wide spectrum nematicide, fungicide and herbicide (Leocata et al., 2014; Myrta et al., 2018).

Therefore, in this article, we report the experiences carried out in Hungary on the effectiveness of the new fumigant Paladin/Accolade EC (94.1\%) applied as soil fumigant treatment against the root-knot nematode $M$. incognita infecting cucumber plants grown in protected conditions, and its herbicidal effect.

\section{Materials and Methods}

\section{Site and experimental design}

The trial was conducted in 2017-2018 in a polytunnel located at Csány (Heves county, Hungary) (47³9'22.6” N, 1949'29.4” E) with a silt loam soil having a pH of 7.8 and effective drainage. The region is a major national producer of cucurbits, with the main 
crop being traditionally watermelon and recently, cucumber as well. The area is relatively flat, with a slope of only $0.5 \%$. The tillage system of the area is considered conventional. The targeted pest species, M. incognita, was present as second stage juveniles (J2) in $100 \%$ of the preliminary collected samples.

The infested soil was deeply ploughed, rotavated and subdivided into $6 \mathrm{~m} \times 5.6 \mathrm{~m}$ plots, spaced $1 \mathrm{~m}$ apart from each other in a randomized complete block design, with four replications for each treatment.

\section{Treatments}

The treatments of the first crop were: (i) the fumigant nematicide Accolade EC (DMDS 94.1\%), (ii) the non-fumigant nematicide Nemathorin $10 \mathrm{G}$ (fosthiazate 10\%) and (iii) an untreated control. Accolade EC (DMDS 94.1\%) as emulsifiable concentration (EC) at the rate of $4001 /$ ha was applied via drip lines running on the soil surface covered by a plastic TIF (Totally Impermeable Film). There were seven driplines per plot spaced $0.8 \mathrm{~m}$ apart in $6 \mathrm{~m}$ length. Drippers (flow rate $2 \mathrm{l} / \mathrm{h}$ ) along the driplines were at $0.1 \mathrm{~m}$ from each other and the propellant was water at a pressure of 2.2 bars. The Accolade EC tank was connected to the water source, and the formulated homogeneous liquid was distributed into the irrigation system. The fumigant was applied on 26 October 2017. Soil temperature was $15.6^{\circ} \mathrm{C}$, and soil humidity (field capacity conditions) were as requested for the DMDS application.

DMDS was applied by BT Agroservizi (Italy) and supervised by Certis Europe team. On 17 January 2018, 83 days after the treatment, the plastic films covering the treated plots were removed.

As a standard nematicide for the region, Nemathorin $10 \mathrm{G}$, a broad-spectrum systemic and contact nematicide formulated as granules containing the active ingredient fosthiazate at $10 \% \mathrm{~W} / \mathrm{W}$, was applied at a rate of $30 \mathrm{~kg} / \mathrm{ha}$ on 4 April 2018. The nematicide was evenly distributed on the plot surface and then incorporated into the soil. The second crop cycle was not treated with nematicides.

\section{Crop}

Cucumber (Cucumis sativus Monolit F1) seedlings were transplanted on 4 April 2018 (first crop) and on 10 July 2018 (second crop) when the soil was adequately moist and finely prepared. There were 6 rows and a total of 120 plants per plot. Cucumber seedlings were spaced $25 \mathrm{~cm}$ apart along the row and $120 \mathrm{~cm}$ between rows. Crop management protocol was as recommended in the region for polytunnel cucumber production: a vertical growing system combined with hand harvest. The first crop was terminated on 25 June 2018, and the second on 21 September 2018.

\section{Crop vigour and yield}

Vigour of the crop was assessed on a 10-1 linear scale, where $10=$ the most vigorous plant within the trial area and $1=$ dead plant. This allowed us also to check for any symptoms of phytotoxicity caused by the treatments. Plant vigour was evaluated on 
11 and 18 June 2018, nine and ten weeks after transplanting. Data for vigour mapping of the plant stand were collected on 18 June 2018.

Fruits of the first crop cycle were harvested 6 times from 2 to 18 June 2018, and yield of 40 plants per plot from the two middle rows was recorded. Cumulated yield of 40 plants per plot within this period was considered a 'sample'.

\section{Root gall index}

At the end of each crop cycle all cucumber plants, in each plot, were carefully uprooted and the roots evaluated for the root gall index (RGI) caused by nematodes. RGI was evaluated according a 0-10 scale proposed by Zeck (Zeck, 1971). In the Zeck's scale, $0=$ no galls, $1=$ very few small galls, $2=$ numerous small galls, $3=$ numerous small galls of which some are grown together, $4=$ numerous small and some big galls, $5=25 \%$ of roots severely galled, $6=50 \%$ of roots severely galled, $7=75 \%$ of roots severely galled, $8=$ no healthy roots but plant is still green, $9=$ roots rotting and plant dying, $10=$ plant and roots dead.

Root gall indices were assessed on 30 September 2017 of all plants of the previous crop of the first cucumber cycle. On 25 June 2018 RGI was assessed for all plants of the first crop cycle, and on 21 September 2018 for the plants from the central coupled rows of each plot for the second crop cycle. Mapping and visualization of root galling was done after RGI evaluation (Leocata, 2020) (in press).

\section{Nematode infestation}

To evaluate soil nematode population density, soil samples were collected after the final harvest of the first crop cycle, on 30 May 2018. Four sub-samples were collected from each plot in the $10-20 \mathrm{~cm}$ soil profile of the root zone and mixed to obtain a representative sample of $0.5 \mathrm{~kg}$. Active nematodes were extracted from $25 \mathrm{~g}$ soil per sample using the modified Baermann funnels (Szakálas et al., 2015). Funnels were left undisturbed for 24 hours and then the clamp was released to collect the nematode-water suspension. Nematodes were then examined under a transmission stereomicroscope (Olympus SZH 10) at $30 \times$ magnification. Total number of free-living nematodes and $\mathbf{J} 2$ larval stage of Meloidogyne species were counted. All non-phytoparasitic nematodes were considered as non-target nematodes.

To identify root-knot nematodes at species level, adult females were removed from galls of cucumber roots and their perineal pattern prepared (Hartman and Sasser, 1985) for microscope observation (VWR VisiScope DBL124) at $400 \times$ magnification (Andrássy and Farkas, 1988). The target nematode species was identified as M. incognita.

\section{Weed germination}

Soil samples were collected from each plot at two random locations and at three different depths along the soil profile $0-10 \mathrm{~cm}, 10-20 \mathrm{~cm}$ and $20-30 \mathrm{~cm}$ with a total of 72 soil samples. These samples were then transferred into $14 \mathrm{~cm}$ diameter pots and irrigated as needed to observe seed germination. Abundance figures of weed seedlings were recorded when they appeared in the pots. Weed seedlings identified to species level 
were recorded and removed from the pots. Seedlings which perished at very early stage and could not be identified to species level were recorded as 'other monocotyledonous' or 'other dicotyledonous'. Observations were made every week between 26 March and 26 June 2018, and the obtained data were cumulated.

\section{Statistical analysis}

We used Past 3.14 statistical program (Hammer et al., 2001) for data analysis. All data were analysed using One-way ANOVA and Tukey's pairwise comparisons as post-hoc test. When significant effect of the treatment was obtained, the differences between mean values were checked with Levene's test for homogeneity of variance. When ANOVA was not applicable, Kruskal-Wallis test and Mann-Whitney pairwise comparisons with uncorrected p-values were used to compare means.

\section{Results}

\section{Crop vigour and yield}

The average vigour index of cucumber plants treated with DMDS was 6.99 on 18 June 2018, and it was significantly greater than those in plots treated with fosthiazate or in the untreated control. No significant difference between plots treated with fosthiazate and the untreated control was detected (4.25 and 3.58, respectively) (Table 1). No phytotoxic symptoms were observed during the trials and at evaluation times in any treated plot. Also, none of the treatments had significant effect on plant height at any evaluation times (data not reported).

According to Tukey's range test yield (kg/sample) in DMDS treated plots (45.1) was significantly higher than that recorded in the untreated control (16.6) (Table 1). No statistically significant difference was observed between the yield of fosthiazate (30.9) and the other treatments (chemical and untreated control).

\section{Root-gall index (RGI) and root mapping}

The roots of first crop were examined on 25 June 2018, after the final harvest. Root damage, according to the Zeck galling index scale, was the lowest (1.17) in plots treated with DMDS in comparison to those observed on roots of plants grown in plots treated with fosthiazate (4.91) or in the untreated control (5.86) (Table 2). On 21 September 2018, at the end of the second crop cycle, cucumber roots were severely damaged in the untreated control (8.44) and in fosthiazate-treated plots (9.18). RGI was significantly less severe (5.58) on DMDS-treated roots in comparison to other treatments (Table 2, Fig. 1). The death of plants that occurred in some plots may be attributed to co-existing soil pathogens which were not investigated. 


\section{Soil nematode population density}

Treatments with DMDS resulted in a significant decrease of soil nematode population density ( 0.25 active juveniles/ $25 \mathrm{~g}$ soil) in comparison to the untreated control (78.0) and the fosthiazate (48.5) (Table 3). Density of non-target nematodes did not differ significantly among treatments, as it was 270.8, 353.8 and 475.3 for DMDS, fosthiazate, and untreated control, respectively (Table 3).

\section{Table 1}

Vigour of plants according to a 1-10 scale and cumulative yield (kg/plot) of cucumber plants naturally infested by Meloidogyne incognita and treated with Accolade EC (DMDS), Nemathorin $10 \mathrm{G}$ (fosthiazate), or untreated, in protected conditions. Plants were evaluated for vigour on 18 June 2018; yield was measured between 2 July and 18 July; "sample" = yield of 40 plants/plot)

\begin{tabular}{llllll}
\hline Target & Measure & Parameter & DMDS & Fosthiazate & Untreated \\
\hline Plant vigour & vigour scale & average & 6.99 & 4.25 & 3.58 \\
& $10-1$ & CI 95\% & 0.91 & 0.50 & 1.24 \\
& & & $\mathrm{a}$ & $\mathrm{b}$ & $\mathrm{b}$ \\
Yield & \multirow{2}{*}{$\mathrm{kg} /$ sample } & average & 45.10 & 30.90 & 16.63 \\
& & CI 95\% & 12.96 & 7.70 & 5.85 \\
& & $\mathrm{a}$ & $\mathrm{ab}$ & $\mathrm{b}$ \\
\hline
\end{tabular}

Different letters indicate significant difference at $\mathrm{p}<0.05$ level according to Tukey's post-hoc test of One-way ANOVA.

\section{Table 2}

Rot-gall index (RGI), according to Zeck's scale (0-10), of protected cucumber plants naturally infested with Meloidogyne incognita. The first date (30 September 2017) refers to the state of the precrop before treatments.

The second and third date (25 June and 21 September 2018) refer to the state of the first and second crop, respectively after treatments

\begin{tabular}{|c|c|c|c|c|c|c|}
\hline Date & Target & Measure & Parameter & DMDS & Fosthiazate & Untreated \\
\hline \multirow[t]{3}{*}{30 Sept 2017} & \multirow{3}{*}{$\begin{array}{l}\text { RGI precrop } \\
\text { (before treatment) }\end{array}$} & \multirow[t]{3}{*}{ Zeck scale $0-10$} & average & 4.11 & 4.86 & 4.53 \\
\hline & & & CI $95 \%$ & 1.41 & 0.78 & 1.25 \\
\hline & & & & $\mathrm{a}$ & a & $\mathrm{a}$ \\
\hline \multirow[t]{6}{*}{25 June 2018} & \multirow[t]{3}{*}{ RGI 1st crop } & \multirow[t]{3}{*}{ Zeck scale $0-10$} & average & 1.17 & 4.91 & 5.86 \\
\hline & & & CI $95 \%$ & 0.59 & 1.41 & 2.02 \\
\hline & & & & $\mathrm{a}$ & $\mathrm{b}$ & $\mathrm{b}$ \\
\hline & \multirow{3}{*}{$\begin{array}{l}\text { RGI change rate } \\
1 \text { st crop/precrop }\end{array}$} & \multirow[t]{3}{*}{ rate 0 -infinity } & average & $28 \%$ & $109 \%$ & $128 \%$ \\
\hline & & & CI $95 \%$ & $10 \%$ & $44 \%$ & $15 \%$ \\
\hline & & & & $\mathrm{a}$ & $\mathrm{b}$ & $\mathrm{b}$ \\
\hline \multirow[t]{6}{*}{21 Sept 2018} & \multirow[t]{3}{*}{ RGI 2nd crop } & \multirow[t]{3}{*}{ Zeck scale $0-10$} & average & 5.58 & 9.18 & 8.44 \\
\hline & & & CI $95 \%$ & 0.61 & 0.27 & 0.57 \\
\hline & & & & $\mathrm{a}$ & $\mathrm{b}$ & $\mathrm{b}$ \\
\hline & \multirow{3}{*}{$\begin{array}{l}\text { RGI change rate } \\
\text { 2nd crop/precrop }\end{array}$} & \multirow[t]{3}{*}{ rate 0 -infinity } & average & $142 \%$ & $196 \%$ & $197 \%$ \\
\hline & & & CI $95 \%$ & $33 \%$ & $48 \%$ & $49 \%$ \\
\hline & & & & $\mathrm{a}$ & a & $\mathrm{a}$ \\
\hline
\end{tabular}

Different letters indicate significant differences at $\mathrm{p}<0.05$ level according to Tukey's post-hoc test of One-way ANOVA. 


\section{Weed germination}

The herbicidal effect of DMDS was found during the first cucumber cycle, and it was significant $(p=0.04)$ only on total of dicotyledonous weeds and within the $20-30 \mathrm{~cm}$ layer of the soil profile. The cumulative numbers of germinating weeds in the soil samples were 1.13, 2.63 and 4.25 per pots for DMDS, fosthiazate and the untreated control, respectively (Table 4).

\section{Discussion}

Since its first development, DMDS, as alternative to conventional fumigants, has been proven to have a very effective control of root-knot nematodes (Charles and Heller, 2010). Recent papers have reviewed its use in protected tomato in Spain, Italy and Greece
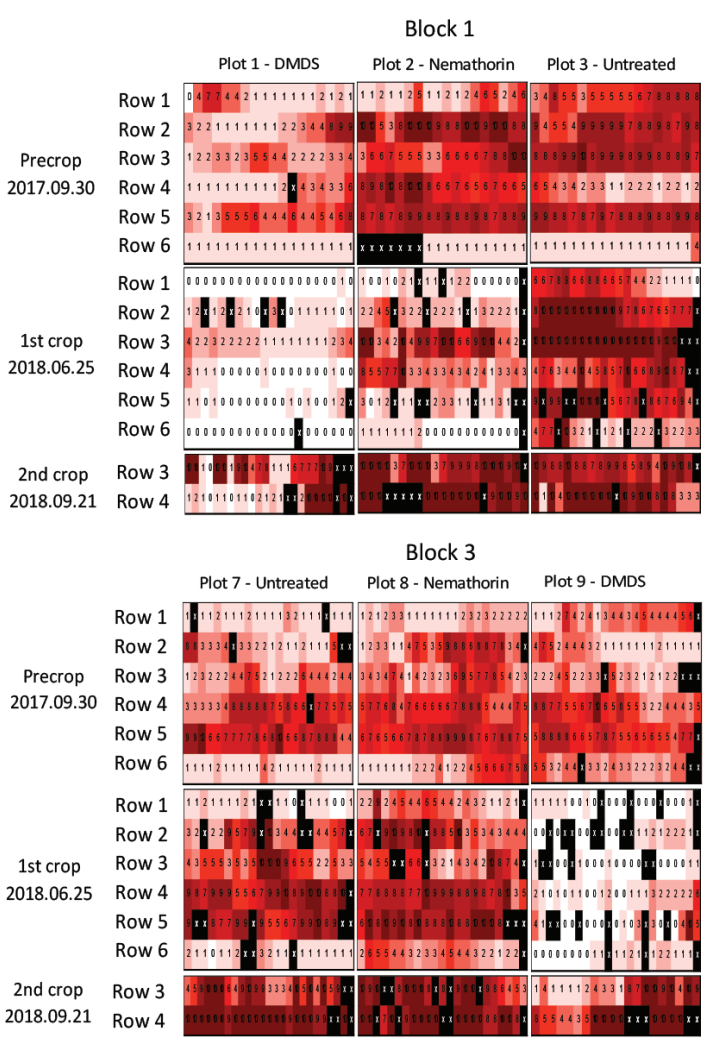

Block 2

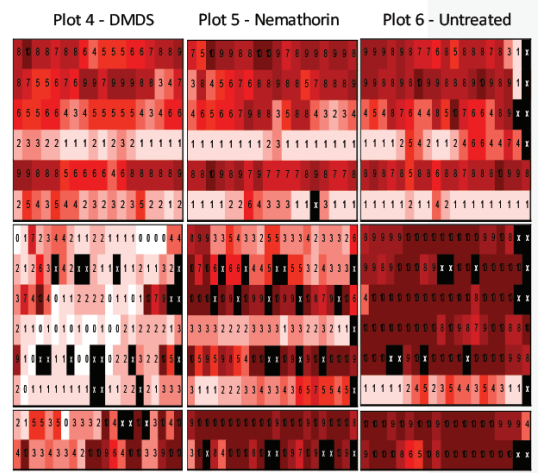

Block 4

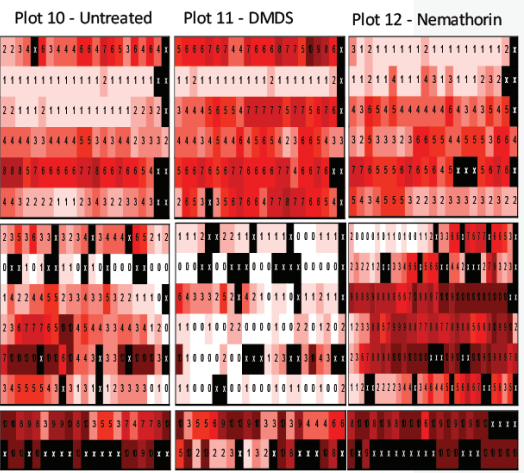

Fig. 1. Root-gall index (RGI), according to Zeck's scale (0-10), of individual cucumber roots from a protected crop grown in soil naturally infested with Meloidogyne incognita.

The data of 30 September 2017 refers to the pre-crop before any treatment; the second and third date

(25 June and 21 September 2018) refer to the state of the first and second crop, respectively, after treatments with Accolade EC (DMDS) and Nemathorin $10 \mathrm{G}$ (fosthiazate).

Darker colour indicates higher RGI value; Black cells marked with " $\mathrm{x}$ ” indicate missing plants 
Table 3

Average density of the invasive juveniles (J2-stage) of Meloidogyne incognita and non-target nematodes in soil samples collected from naturally infested cucumber plots treated with Accolade EC (DMDS), Nemathorin $10 \mathrm{G}$ (fosthiazate) or in untreated plots

\begin{tabular}{lllccc}
\hline Target & Measure & Parameter & DMDS & Fosthiazate & Untreated \\
\hline Meloidogyne incognita J2 & no. indiv./ 25 g soil & average & 0.25 & 48.50 & 78.00 \\
& & CI 95\% & 0.49 & 55.73 & 83.36 \\
& & $\mathrm{a}$ & $\mathrm{b}$ & $\mathrm{b}$ \\
Non-target nematodes & & average & 270.8 & 353.8 & 475.3 \\
& & CI 95\% & 213.4 & 334.0 & 281.7 \\
& & $\mathrm{a}$ & $\mathrm{a}$ & $\mathrm{a}$ \\
\hline
\end{tabular}

Different letters indicate significant difference at $\mathrm{p}<0.05$ level according to Mann-Whitney pairwise comparisons of Kruskal-Wallis test (M. incognita J2), and Tukey's post-hoc test of One-way ANOVA (non-target nematodes).

\section{Table 4}

Number of germinating dicotyledonous weeds within the 20-30 cm soil layer of protected cucumber crop untreated or treated with Accolade EC (DMDS) and Nemathorin $10 \mathrm{G}$ (fosthiazate) between 26 March and 26 June 2018

\begin{tabular}{llllll}
\hline Target & Measure & Parameter & DMDS & Fosthiazate & Untreated \\
\hline $\begin{array}{l}\text { Dicot. germination from } \\
\text { 20-30 cm soil depth }\end{array}$ & no. seedlings/sample & average & 1.13 & 2.63 & 4.25 \\
& & CI 95\% & 0.84 & 1.98 & 1.17 \\
& & $\mathrm{a}$ & $\mathrm{ab}$ & $\mathrm{b}$ \\
\hline
\end{tabular}

Different letters indicate significant differences at $\mathrm{p}<0.05$ level according to Tukey's post-hoc test of One-way ANOVA.

(Myrta et al., 2018), in lettuce in Italy (Gilardi et al., 2017), and in various vegetables, including cucumber and strawberry in Spain, Italy and France (Greco et al., 2018).

No phytotoxic effect caused by DMDS was recorded in the cucumber trial in protected conditions. This agrees with earlier findings on tomato, melon, cucumber and pepper grown in protected conditions (Leocata et al., 2014; Zanón et al., 2014a; Myrta et al., 2018). Only at a very high rate (600 1/ha) has DMDS been reported to reduce the germination of lettuce seeds in protected environment (Gómez-Tenorio et al., 2018). At doses lower than 400 1/ha no negative effect on lettuce seed germination was observed. In a previous experiment on lettuce DMDS was found to be phytotoxic in vermiculite but not in soil when these substrates were used as a culture medium (Gómez-Tenorio et al., 2015).

In our experiment, the effect of DMDS on cucumber seed germination was not assessed because we used cucumber seedlings. Prior to obtaining any data on soil nematode population density, weed abundance and yield, a visible positive effect of DMDS on the health status of the cucumber crop was evident. The positive effect of DMDS on plant growth agrees with previous results obtained by Mao et al. (2016) on the same crop. In our study, DMDS significantly increased plant vigour and cucumber yield in comparison to untreated control. Significant yield increases with DMDS treatments were also observed in melon and tomato (Leocata et al., 2014; Sasanelli et al., 2014), in cucumber 
and pepper (Zanón et al., 2014a), in ornamental cockscomb and chrysanthemum (Rosskopf et al., 2006, Pecchia et al., 2017), and, as previously reported, in lettuce (Gilardi et al., 2017). A recent review, summarizing the results of several experiments conducted throughout Southern Europe (Myrta et al., 2018) with soil fumigants, including DMDS, resulted in yield increases in comparison to untreated controls. Moreover, in a comprehensive study DMDS was found to be more effective than reference fumigants confirming our results (Greco et al., 2018).

In our trials, plants in DMDS treated plots showed significantly lower root gall indices when compared to fosthiazate or to the untreated control. In a greenhouse study on tomatoes, the effect of DMDS on root gall formation was evaluated considering the time of appearance of galls after transplanting. In this experiment, galls were developed first in untreated plots, followed by plots treated with a conventional nematicide (non-fumigant), and much later in DMDS treated plots (Gómez-Tenorio et al., 2018).

In a second crop cycle without DMDS application, plants suffered nematode damage (Desaeger and Csinos, 2006). In our trials, the control of the root-knot nematode in the second crop cycle avoiding a second DMDS application was clear and acceptable, keeping the damage significantly lower than those of the standard treatment or the untreated control. Root gall indices in the second crop were higher than those observed in the first crop, indicating that a second DMDS application may be necessary before a third crop cycle. It was also observed that the beneficial effect of a single application of DMDS before the first crop lasted until the termination of the second crop as well (Gómez-Tenorio et al., 2018). We found that non-target nematodes were affected less by DMDS than root-knot nematodes. New nematode soil population studies after DMDS fumigation show that the populations of root-knot nematodes remain much lower also one year after fumigation in comparison to untreated control, while populations of non-target nematodes recovered totally (Ilieva and Myrta, unpublished data).

Since weeds compete with the main crop for space, nutrients and water, they are not tolerated within intensive production systems. The herbicidal effect of a nematicide sometimes is an additional benefit. In our study DMDS was able to suppress the germination of dicotyledonous weeds occurring in the $20-30 \mathrm{~cm}$ soil profile. This finding leads us to consider that the depth of $20-30 \mathrm{~cm}$ is the level of herbicidal action of DMDS. In this study the DMDS herbicidal effect was not expressed towards monocotyledonous weeds in any crop cycle, although other investigations proved the contrary. In a two-year study, DMDS, alone or in combination with other herbicides, was effective to control monocotyledonous nutsedge (Cyperus rotundus L., 1753) populations (Stevens and Freeman, 2018).

\section{Conclusions}

The DMDS trials carried out for the first time in Hungary in a location representative of the most important growing areas of protected cucumber confirm previous results on the efficacy of DMDS for controlling root-knot nematodes in other countries (Curto et al., 2014; Sasanelli et al., 2014). DMDS is under EU process of evaluation for inclusion in Annex 1. In view of its future EU registration, DMDS is expected to represent a new effective technical solution against plant parasitic nematodes for European vegetable growers. 
Damage caused by root-knot nematodes in protected crops suggests a pre-planting soil fumigation to obtain satisfactory crop yield (Sikora and Fernandez, 2005). For protected crops post-planting chemicals or organic nematicides are also available, but these are not as effective as nematicide fumigants (Greco et al., 2018). DMDS, appropriately included in IPM programs, appears a promising and effective tool to control plant-parasitic nematodes as already proposed by Certis Europe in its CleanStart ${ }^{\mathrm{TM}}$ program for sustainable soil management (Zanón et al., 2014b).

\section{Acknowledgments}

We would like to express our thanks to dr. Nicola Greco, formerly a research leader at the Institute for Sustainable Plant Protection of CNR (Italy), for his critical reading and suggestions to improve the manuscript; the farmer, Mrs. Piroska Szabó for providing the cucumber stand and all necessary help during the experiment, and to the personnel of BT Agroservizi (Italy) for the application of DMDS, and Péter Nagy, senior nematologist of the Szent István University, Faculty of Agricultural and Environmental Sciences, Department of Zoology and Animal Ecology (Hungary) for providing laboratory infrastructure for the nematological analysis. Research work was partly supported by the Higher Education Institutional Excellence Program (1783-3/2018/FEKUTSTRAT) awarded by the Ministry of Human Capacities within the framework of plant breeding and plant protection research program at Szent István University.

\section{Literature}

Andrássy, I. (1958): Szabadon élő fonálférgek (Nematoda libera) [Free-living nematodes]. Fauna Hungariae, Academic Press, Budapest, Hungary, 362 p.

Andrássy, I. and Farkas, K. (1988): Kertészeti növények fonálféreg kártevői [Plant parasitic nematodes of horticultural crops]. Mezőgazdasági Kiadó, Budapest, Hungary, 419 p.

Arnault, I., Vey, F., Fleurance, C., Nabil, H. and Auger, J. (2008): Soil fumigation with Allium sulfur volatiles and Allium by-products. 16th International Federation of Organic Agriculture Movements (IFOAM) Organic World Congress, Modena, Italy, June 16-20, 2008.

Basile, M., D’Addabbo, T., Sasanelli, N. and Basile A. C. (2003): Fumiganti e nematicidi sistemici in vivaio [Systemic fumigants and nematicides in the nursery]. Italus Hortus, 10, 294-296.

Charles, P. and Heller, J. J. (2010): Efficacy of DMDS as a soil treatment against Meloidogyne chitwoodi in The Netherlands. Acta Hortic. 883, 195-198. doi: 10.17660/Actahortic.2010.883.23

Chindo, P. S., Khan, F. A. and Erinle, I. D. (1991): Reaction of three tomato cultivars to vascular diseases in presence of the root-knot nematode Meloidogyne incognita race 1. Crop Prot. 10, 62-64. doi: 10.1016/02612194(91)90028-P

Chitwood, B. G. (1949): Root-knot nematodes - Part I. A revision of the genus, Meloidogyne Goeldi 1887. Proc. Helminthol. Soc. Wash. 16, 90-104.

Curto, G., Dongiovanni, C., Sasanelli, N., Santori, A. and Myrta, A. (2014): Efficacy of Dimethyl Disulfide (DMDS) in the control of the root-knot nematode Meloidogyne incognita and the cyst nematode Heterodera carotae on carrot in field condition in Italy. Acta Hort. 1044, 405-410. https://doi.org/10.17660/ actahortic.2014.1044.58

Dabaj, K. H., Jenser, G. és Farkas, K. (1994): Distribution and host plant of root-knot nematodes (Meloidogyne) in Hungary. Acta Zool. Acad. Sci. Hung. 40, 125-131.

Desaeger, J. A. and Csinos, A. S. (2006): Root-knot nematode management in double-cropped plasticulture vegetables. J. Nematol. 38, 59-67.

Fauna Europaea (2019): Available online: https://fauna-eu.org/ (accessed on 22 February 2019)

Gallo, M., Ciccarese, F. and Sasanelli, N. (2011): Control of Pyrenochaeta lycopersici and Meloidogyne incognita on tomato by eco-compatible treatments. Acta Hort. (ISHS) 914, 341-344. 
Gautier, H. (2007): Study of the effects of an Allium-derivative compound, dimethyl disulfide, on insect neurons and on mice electroencephalographic activity. (Etude des effets d'un composé soufré liberé par les $A l$ lium, le disulfure de diméthyle, sur les neurones d'insecte et sur l'activité electroencephalographique de souris). Doctoral Thesis, Angers University, France

Gilardi, G., Gullino, M. L. and Garibaldi, A. (2017): Soil disinfestation with dimethyl disulfide for management of Fusarium wilt on lettuce in Italy. J. Plant Dis. Protect. 124, 361-370. doi: 10.1007/s41348-017-0071-2

Gómez-Tenorio, M. A., Zanón, M. J., de Cara, M., Lupión, B. and Tello, J. C. (2015): Efficacy of dimethyl disulfide (DMDS) against Meloidogyne sp. and three formae speciales of Fusarium oxysporum under controlled conditions. Crop Prot. 78, 263-269. doi: 10.1016/j.cropro.2015.09.013

Gómez-Tenorio, M. A., Tello, J. C., Zanón, M. J. and de Cara, M. (2018): Soil disinfestation with dimethyl disulfide (DMDS) to control Meloidogyne and Fusarium oxysporum f. sp. radicis-lycopersici in a tomato greenhouse. Crop Prot. 112, 133-140. doi: 10.1016/j.cropro.2018.05.023

Greco, N. and Di Vito, M. (2009): Population dynamics and damage levels. In: R. N. Perry, M. Moens and J. L. Starr (eds): Root-Knot Nematodes. CAB International, Wallingford, UK, pp. 246-274. doi: $10.1079 / 9781845934927.0246$

Greco, N., López Aranda, J. M., Saporiti, M., Maccarini, C., de Tommaso, N. and Myrta, A. (2018): Sustainability of European vegetable and strawberry production in relation to fumigation practices in EU. II. International Symposium on Carrot and Other Apiaceae. Krakov, Poland, 19-22 September 2018.

Hammer, Ø., Harper, D. A. T. and Ryan, P. D. (2001): PAST: Paleontological statistics software package for education and data analysis. Palaeontol. Electronica 4, 1-9. http://dx.doi.org/10.1002/9780470750711

Hartman, K. M. and Sasser, C. C. (1985): Identification of Meloidogyne species on the basis of differential host test and perineal-pattern morphology. In: K. R. Barker, C. C. Carter and J. N. Sasser (eds): An Advanced Treatise on Meloidogyne. Vol. II: Methodology, North Carolina State University Graphics, Raleigh, North Carolina, 69-78.

Leocata, S. (2020): La valutazione dell'indice galligeno sulla coltura precedente come metodo affidabile per il posizionamento di prove sperimentali sui nematodi delle serre in Sicilia. Atti Giornate Fitopatologiche. (in press).

Leocata, S., Pirruccio, G., Medico, E., Myrta, A. and Greco, N. (2014): Dimethyl disulfide (DMDS): A new soil fumigant to control root-knot nematodes, Meloidogyne spp., in protected crops in Sicily, Italy. Acta Hortic. 1044, 415-420. doi: 10.17660/actahortic.2014.1044.57

Mao, L.-G., Wang, Q.-X., Yan, D.-D., Liu, P.-F., Shen, J., Fang, W.-S., Hu, X.-M., Li, Y., Ouyang, C.-B., Guo, M.-X. and Cao, A.-C. (2016): Application of the combination of 1,3-dichloropropene and dimethyl disulfide by soil injection or chemigation: effects against soilborne pests in cucumber in China. J. Integr. Agric. 15, 145-152. https://doi.org/10.1016/S2095-3119(15)61065-6

Marley, P. S. and Hillocks, R. J. (1996): Effect of root-knot nematodes (Meloidogyne spp.) on fusarium wilt in pigeonpea (Cajanus cajan). Field Crop. Res. 46, 15-20. doi: 10.1016/0378-4290(95)00083-6

Mándoki, Z. and Pénzes, B. (2012): Effects of using chemical-free root-knot nematode (Meloidogyne incognita) control methods on the occurrence of blossom-end rot in pepper. J. Plant Prot. Res. 52, 337-341. doi: 10.2478/v10045-012-0055-y

Myrta, A., Santori, A., Zanon, M. J., Tsimboukis, N., de Vries, R. and de Tommaso, N. (2018): Effectiveness of dimethyl disulfide (DMDS) for management of root-knot nematode in protected tomatoes in Southern Europe. Acta Hortic. 1207, 123-127. doi: 10.17660/ActaHortic.2018.1207.16

Peacock, F. C. (1976): Nematodes and crop disease. Outlook Agric. 8, 328-334. doi: 10.1177/003072707600800604

Pecchia, S., Franceschini, A., Santori, A., Vannacci, G. and Myrta, A. (2017): Efficacy of dimethyl disulfide (DMDS) for the control of chrysanthemum Verticillium wilt in Italy. Crop Prot. 93, 28-32. doi: 10.1016/j. cropro.2016.11.019

Rosskopf, E. N., Church, G., Holzinger, J., Yandoc-Ables, C. and Noling, J. (2006): Efficacy of dimethyl disulfide (DMDS) for control of nematodes and fungal plant pathogens. Phytopathology 96, S100.

Sasanelli, N., Ciccarese, F. and Papajová, I. (2008): Aphanocladium album by sub-irrigation in the control of Pyrenochaeta lycopersici and Meloidogyne incognita on tomato in a plastic-house. Helminthologia, 45, 137-142. DOI: 10.2478/s11687-008-0027-y

Sasanelli, N., Dongiovanni, C., Santori, A. and Myrta, A. (2014): Control of the root-knot nematode Meloidogyne incognita by dimethyl disulfide (DMDS) applied in drip irrigation on melon and tomato in Apulia (Italy). Acta Hortic. 1044, 401-404. doi: 10.17660/ActaHortic.2014.1044.54 
Sasanelli, N., Toderas, I., Ciccarese, F., Erhan, D., Rusu, S., Bivol, A. and Iurcu-Straistaru, E. (2016): Biological limitators in the control of Meloidogyne incognita and Verticillium dahliae on eggplant. IXth International Conference of Zoologists "Sustainable use, protection of animal world and forest management in the context of climate change", 12-13 October, Chisinau, Republic of Moldova, 160-161. ISBN 9789975-3022-7-2.

Sasanelli, N., Toderas, I., Ircu-Straistaru, E., Rusu, S., Migunova, V. and Konrat, A. (2018): Yield losses caused by plant parasitic nematodes graphical estimation. International Symposium "Functional Ecology of Animals", Chisinau, 21 September 2018, 319-329.

Sasser, J. N. (1977): Worldwide dissemination and importance of the root-knot nematodes, Meloidogyne spp. J. Nematol. 9, 26-29.

Sikora, R. A. and Fernandez, E. (2005): Nematode parasites of vegetables. In: M. Luc, R. A. Sikora and J. Bridge (eds): Plant Parasitic Nematodes in Subtropical and Tropical Agriculture. 2nd ed. CAB International, Wallingford, UK, pp. 319-392.

Stevens, M. and Freeman, J. (2018): Efficacy of dimethyl disulfide and metam sodium combinations for the control of nutsedge species. Crop Prot. 110, 131-134. doi:10.1016/j.cropro.2018.04.010

Sumner, D. R. and Johnson, A. W. (1973): Effect of root-knot nematodes on Fusarium wilt of watermelon. Phytopathology 63, 857-861. doi: 10.1094/Phyto-63-857.

Szakálas, J., Kröel-Dulay, Gy., Kerekes, I., Seres, A., Ónodi, G. and Nagy, P. (2015): Extrém szárazság és a növényzeti borítottság hatása szabadon élö fonálféreg együttesek denzitására. [Effects of extreme drought manipulation on free-living nematode densities]. Természetvédelmi Közlemények 21, 293-300.

Wheeler, T. A., Siders, K. T., Anderson, M. G., Russell, S. A., Woodward, J. E. and Mullinix, B. G. Jr. (2014): Management of Meloidogyne incognita with chemicals and cultivars in cotton in a semi-arid environment. J. Nematol. 46, 101-107.

Zanón, M. J., Guitierrez, L. A. and Myrta, A. (2014a): Spanish experiences with dimethyl disulfide (DMDS) in fruiting vegetables. Acta Hortic. 1044, 421-426. doi: 10.17660/ActaHortic.2014.1044.58

Zanón, M. J., Santori, A., Fargier, P., De Tommaso, N., De Vries, R. and Myrta, A. (2014b): Cleanstart: the program for sustainable soil pest management from Certis Europe. Acta Hort. 1044: 395-400 https://doi. org/10.17660/actahortic.2014.1044.53. CrossRef

Zeck, W. M. (1971): A rating scheme for field evaluation of root-knot infestations. Pflanzenschutz-Nachr. Bayer AG 24, 141-144.

This is an open-access article distributed under the terms of the Creative Commons Attribution 4.0 International License (https://creativecommons.org/licenses/by/4.0/), which permits unrestricted use, distribution, and reproduction in any medium, provided the original author and source are credited, a link to the CC License is provided, and changes - if any - are indicated. (SID_1) 